\title{
Acute aerobic swimming exercise increases nucleotidase activities in rat blood serum
}

\author{
Senger $\mathrm{MR}^{1}$, Pedrazza $\mathrm{EL}^{2}$, Oliveira $\mathrm{AR}^{3}$, Bonan $\mathrm{CD}^{2}$ \\ ${ }^{1}$ Laboratório de Bioquímica de Proteínas e Peptídeos, Instituto Oswaldo Cruz - FIOCRUZ, Rio de Janeiro, Brasil \\ ${ }^{2}$ Laboratório de Neuroquímica e Psicofarmacologia, Departamento de Biologia Celular e Molecular, Faculdade \\ de Biociências, Pontifícia Universidade Católica do Rio Grande do Sul, Porto Alegre, Brasil \\ ${ }^{3}$ Escola de Educação Física, Universidade Federal do Rio Grande do Sul, Porto Alegre, Brasil
}

\begin{abstract}
Objective: The purpose of this investigation was to examine the effect of an acute swimming exercise session on nucleotidase activities in rat blood serum. Methods: Male Wistar rats were divided in exercise and sedentary groups. In the exercise group, rats were submitted to one swimming session (60 minutes) with a constant load of $4 \%$ of body weight in the tail. Nucleotidase activities were gauged spectrophotometrically by measuring the inorganic phosphate from ATP, ADP or AMP hydrolysis or p-nitrophenol released from of p-Nph-5'TMP hydrolysis. Results: The exercise group presented a significant increase in nucleoside triphosphate diphosphohydrolase (55.5\% and $43.1 \%$, for ATP and ADP, respectively), 5'nucleotidase $(57.4 \%)$, and nucleotide pyrophosphatase/phosphodiesterase $(24.2 \%)$ activities. Conclusion: Our results have shown that nucleotidases are activated in rat blood serum after one session of aerobic swimming exercise, suggesting that these enzymes may promote an increase in adenosine levels, which might contribute to exercise-mediated vasodilatation.
\end{abstract}

Arch Exerc Health Dis 4 (2): 262-266, 2014

Key Words: Acute exercise; rat; serum; nucleotidase; ATP; adenosine

\section{INTRODUCTION}

Adenine nucleotides (ATP, ADP and AMP) and the derived nucleoside adenosine are important signaling molecules in the extracellular space, in which, they play important physiological roles. Evidence shows that nucleotides can be released from erythrocytes, endothelial cells and sympathetic nerve terminals upon muscle contraction $(8,20)$. The physiological stimuli for ATP release in vivo in the vasculature remains to be demonstrated. ATP regulates vascular tonus and cardiac function (24). Studies have shown that ATP, at milimolar concentrations, inhibits platelet aggregation via competitive and non-competitive mechanisms; however, at low concentrations, ATP may be stimulatory (31). It is well established that ADP induces changes in shape and platelet aggregation (18). Different studies have demonstrated the important role of these nucleotides in the processes of homeostasis and thrombi formation $(9,22)$. The nucleoside adenosine, produced by nucleotide degradation, can act as a vasodilator and cardioprotective compound $(12,31)$.

The levels of extracellular nucleotides may be regulated by the action of ecto-nucleotidases and soluble nucleotidases, including enzymes of the NTPDase family (nucleoside triphosphate diphosphohydrolase; EC 3. 6. 1.5), the 5'-nucleotidase (EC 3.1.3.5) and the NPP family (nucleotide pyrophosphatase phosphodiesterase; EC 3. 6. 1. 9) (37, 38). Studies have shown the presence of soluble NTPDases, NPPs, and 5'-nucleotidase in rat blood serum $(21,30)$. This enzyme cascade regulates the availability of ligands (ATP, ADP, AMP, and adenosine) for nucleotide and nucleoside receptors, and therefore the duration and increased receptor activation (7, 29). Roque et al. (2011) demonstrated that nucleotide hydrolysis is increased after moderate exercise training, which produces more adenosine, a potent vasodilator that may contribute to augmented

\footnotetext{
Corresponding author:
}

Mário Roberto Sanger: Laboratório de Bioquímica de Proteínas e Peptídeos, Instituto Oswaldo Cruz - FIOCRUZ, Av. Brasil, 4365, Pavilhão Leonidas Deanne, Sala 309, 21040-360, Rio de Janeiro, RJ, Brazil.•Email: mario.senger@ioc.fiocruz.br 
blood flow. Nucleotide receptors are called P2 purinoceptors, and they are divided into two subclasses, P2X and P2Y. The P2X subclass consists of ionotropic receptors and mediates vasoconstriction. The P2Y subclass consists of metabotropic receptors and mediates vasodilation $(25,4,5)$. Adenosine is a potent vasodilator that mediates its effects by means of a class of receptors called $\mathrm{P} 1$ receptors, which are divided into four subtypes: $A_{1}, A_{2 A}, A_{2 B}$, and $A_{3}(11$, 13).

The precise blood flow and metabolism is especially important for skeletal muscle, where the energy supply demand can vary considerably for inactive or active periods (23). Neural vasoconstrictor activity and locally derived vasoactive substances regulate blood flow. Numerous local factors are released by skeletal muscle, endothelial cells and red blood cells; these factors also can include adenosine, ATP, potassium, hypoxia, hydrogen ion, nitric oxide, prostanoids and endothelium-derived hyperpolarizing factor (8).

Aerobic exercise induces cardiovascular responses such as an increase in heart rate, vasodilation and an increased blood flow, a mechanism necessary for a greater supply of oxygen and nutrients to the muscle during exercise. Considering these facts, this study hypothesized that the degradation pathway of an extracellular nucleotide is activated to produce adenosine, an important vasodilator. Therefore, the objective of this work was to evaluate the effect of acute aerobic swimming on the degradation of nucleotides by measuring NTPDase, NPP, and 5'nucleotidase activities in rat blood serum.

\section{MATERIALS AND METHODS}

\section{Chemicals}

Nucleotides, p-nitrophenyl thymidine 5'monophosphate, trizma base, malachite green, ammonium molybdate, polyvinyl alcohol, EDTA, EGTA, sodium citrate, Coomassie Blue G, bovine serum albumin, calcium and magnesium chloride were purchased from Sigma (USA). All other reagents used were of analytical grade.

\section{Animals}

Male Wistar rats (age-approximately 90 days, weight - 260-320g) from our breeding stock were housed four to a cage, with food and water ad libitum. The animal house temperatures were kept between 22$23{ }^{\circ} \mathrm{C}$ with a 12-hour light/dark cycle (lights on at 7:00). Animal care followed the official governmental guidelines in compliance with the Federation of Brazilian Societies for Experimental Biology.

\section{Acute exercise-test protocol}

The rats were divided in two groups $(n=6)$ : exercise (E) and sedentary (S). The E group was submitted to a 60-minute session of swimming exercise, supporting a constant load of $4 \%$ of body weight in the tail. This weight was chosen because it is already characterized in the literature as an aerobic exercise below the lactate threshold $(15,33)$. The swimming exercise was performed in cylinder tanks $45 \mathrm{~cm}$ deep and $32 \mathrm{~cm}$ in diameter. The sedentary group was placed into the same tank, but the water was added to a depth that the rat could stand on the bottom. The purpose of this procedure was to expose the sedentary group to water stress without promoting exercise stress. The water temperature was kept between $30-34{ }^{\circ} \mathrm{C}$ throughout the experiments (16).

\section{Isolation of blood serum fraction}

Blood samples were collected immediately after the exercise or water stress (34), and centrifuged in plastic tubes at $5000 \mathrm{~g}$ for 5 minutes at $20{ }^{\circ} \mathrm{C}$. The serum samples were maintained on ice and used immediately in the experiments.

\section{Determination of NTPDase and 5'- nucleotidase activities}

ATP, ADP, and AMP hydrolysis were determined as described previously (21). The reaction mixture containing $3.0 \mathrm{mM}$ ATP, ADP, or AMP as substrate, $112.5 \mathrm{mM}$ Tris-HCl, and $\mathrm{pH}$ 8.0, was incubated with $0.7 \mathrm{mg}$ to $1.0 \mathrm{mg}$ of serum protein at $37^{\circ} \mathrm{C}$ for 40 minutes in a final volume of $0.2 \mathrm{~mL}$. The reaction was stopped by the addition of $0.2 \mathrm{~mL}$ of $10 \%$ TCA. The samples were chilled on ice for 10 minutes and centrifuged at $5000 \mathrm{x} \mathrm{g}$ for 5 minutes to eliminate the precipitate protein, and $100 \mu \mathrm{L}$ of supernatant was used for the colorimetric assay. The amount of inorganic phosphate $(\mathrm{Pi})$ released was measured as outlined previously (6). Incubation times and protein concentrations were chosen to ensure the linearity of the reaction. Controls with the serum fraction added after the trichloroacetic acid were used to correct nonenzymatic hydrolysis of the substrates. All samples were run in duplicate. Enzyme activities were expressed as nanomoles of Pi released per minute per milligram of protein.

\section{Determination of nucleotide pyrophosphatase/phosphodiesterase acvtivity (NPP)}

The NPP activity was assessed using p-nitrophenyl 


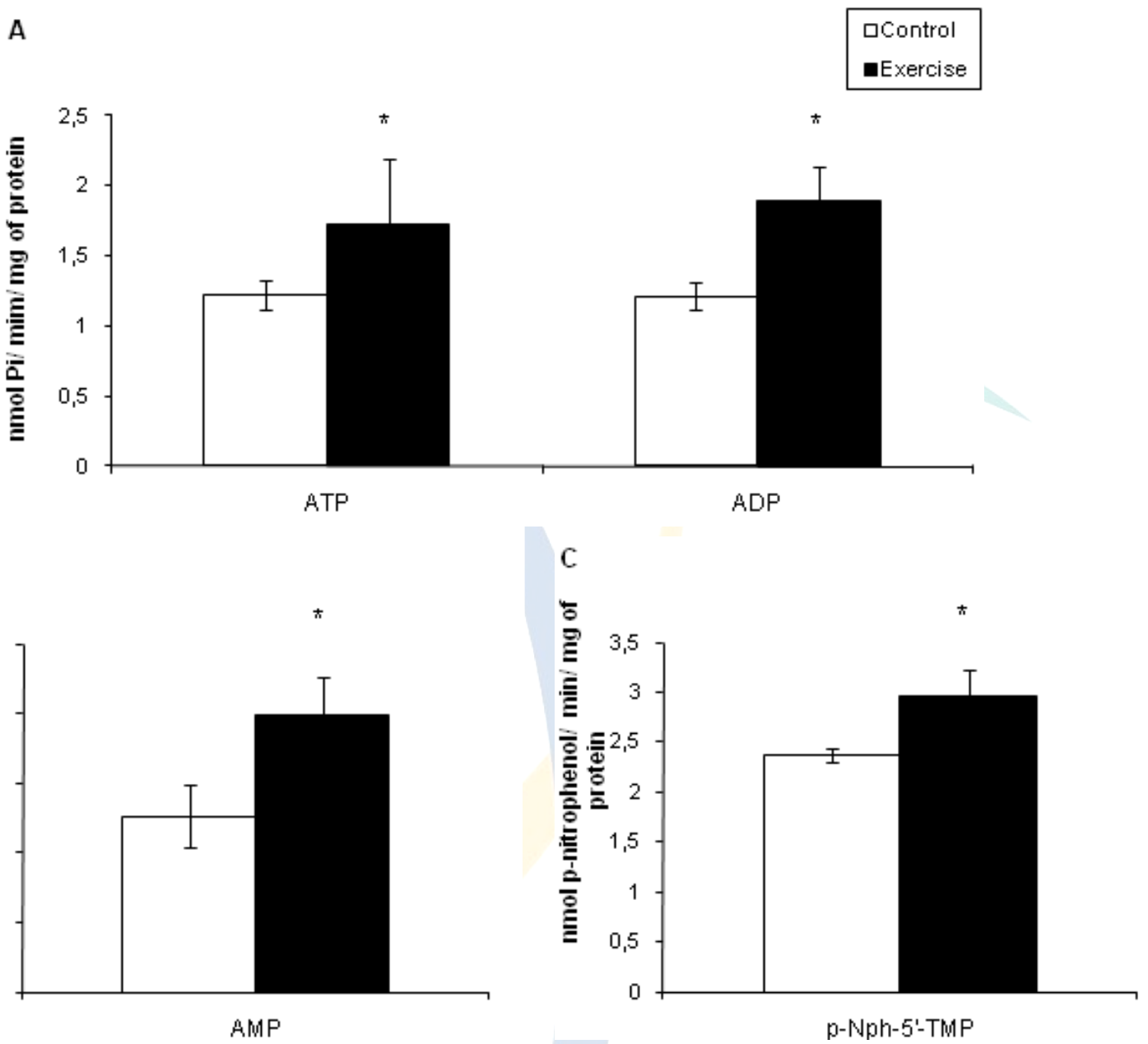

Figure 1. Effect of acute aerobic swimming exercise on serum nucleotide hydrolysis. (A) NTPDase (B) 5 '-nucleotidease (C) NPP activity. Bars represent the mean \pm S.D. of six different experiments. * represents Student t-test considering $P \leq 0.05$ as significant).

thymidine 5'-monophosphate (p-Nph-5'-TMP), an artificial marker routinely used for the assay of this enzyme (30). The reaction mixture containing $0.5 \mathrm{mM}$ of p-Nph-5'-TMP, as a substrate in $100 \mathrm{mM}$ Tris- $\mathrm{HCl}$, $\mathrm{pH} 8.9$, was incubated with approximately $1.0 \mathrm{mg}$ of serum protein at $37^{\circ} \mathrm{C}$ for 8 minutes in a final volume of $0.2 \mathrm{~mL}(21)$. The reaction was stopped by the addition of $0.2 \mathrm{~mL}$ of $0.2 \mathrm{~N} \mathrm{NaOH}$. Incubation times and protein concentrations were chosen to ensure the linearity of the reaction. Controls with the serum fraction added after $\mathrm{NaOH}$ were used to correct nonenzymatic hydrolysis of the substrate. All samples were run in duplicate. Enzyme activity was expressed as nanomoles of p-nitrophenol released per minute per milligram of protein.

\section{Protein determination}

Protein was measured by the Coomassie Blue method (1), using bovine serum albumin as a standard.

\section{Statistical Analysis}

Data were expressed as means $(n=6)+$ S.D and analyzed by Student t-test. $P \leq 0.05$ was considered significant.

\section{RESULTS}

We evaluated the effect of acute swimming exercise on NTPDase, NPP, 5'-nucleotidase in rat blood serum. The data showed that acute swimming exercise resulted in a significant increase in all enzyme activities tested (Fig. 1). There was an increase in ATP $(1.22 \pm 0.1$ vs $1.89 \pm 0.4 ; 55.5 \%)$, ADP $(1.21 \pm 0.1$ vs $1.72 \pm 0.2 ; 43.1 \%$ ) (Fig. 1A), and AMP (1.26 \pm 0.2 vs $1.99 \pm 0.2 ; 57.4 \%$ ) (Fig. 1B) hydrolysis promoted by NTPDase and ecto-5'-nucleotidase activities present in blood serum of the exercise group, respectively, when compared to the control group. NPP activity, performed using the artificial substrate p-Nitrophenyl- 
thymidine-5'-monophosphate (p-Nph-5'-TMP), also increased significantly $(2.37 \pm 0.1$ vs $2.95 \pm 0.2 ; 24.2 \%)$ in blood serum of rats subjected to exercise when compared to the control group (Fig. 1C).

\section{DISCUSSION}

In this study, we demonstrated that the enzymatic activities involved in extracellular nucleotide catabolism in blood serum are increased after an acute swimming exercise session. ATP and other nucleotides are released through lysis and/or cell death, as well as exocytosis. Besides ATP release, it is also important to observe that electrical stimulus also induces the release of soluble enzymes, which may act together with nucleotidases anchored in membranes in the nucleotide hydrolysis in blood serum $(32,35)$. Exercise can induce muscle damage and increase electrical stimulus; therefore it is easy to speculate that an increase in nucleotide and/or nucleotidases concentrations occurs in blood serum during exercise. Mortensen et al. (2011) demonstrated that ATP is released locally into the arterial and venous plasma of contracting muscle. Furthermore, nucleotide hydrolysis (ATP diphosphohydrolase and 5'nucleotidase activity) is increased after chronic swimming training, suggesting that this enzymatic pathway is involved in functional adaptations of exercise (27). In physiological conditions, endothelial NTPDase maintain haemosthasis through the rapid inactivation of released nucleotides (19). The endothelial metabolism generally prevails in microcirculation; however, in the larger veins, the ability to metabolize nucleotides also resides on the luminal surface of the vein wall and in circulating blood (9). Among the blood cellular elements, leukocytes contributed to the catabolism of nucleotides (17), but erythrocytes or platelets did not. The biological effect of nucleotides is mainly determined by its rate of release into the extracellular medium, the nucleotidase activities and their binding affinity to specific receptors (36). Nucleotidase-mediated modulation affects the nucleotide levels and acts on cell signaling mediated by these molecules in different cell types (2). The activation of the nucleotidase activities in rat blood serum after an acute swimming exercise session may decrease the effect of nucleotides (ATP, ADP, and AMP) via $\mathrm{P} 2$ receptors and increase the effect of adenosine via $\mathrm{P} 1$ receptors.

Mortensen et al. (2011) used the intravascular microdialysis technique to show that ATP is rapidly degraded or taken up by cells because only $35-48 \%$ of the infused ATP could be detected in the artery $\sim 20$ $\mathrm{cm}$ downstream from the infusion. The short half-life in vivo of ATP can be caused by a rapid uptake in endothelial cells or degradation by soluble or membrane-bound enzymes. Our study demonstrated an increase in the activity of soluble nucleotidases after exercise, reinforcing the role of this enzymatic pathway on acute physiological changes promoted by exercise.

ATP may have an antagonistic effect on the regulation of muscle blood flow, inducing constriction to maintain systemic blood pressure, and dilation to increase the supply of oxygen (28). It is widely assumed in the literature that the vascular effects of ATP are mediated by second messengers such as nitric oxide, prostacyclin and endothelium-derived hyperpolarizing factors $(10,28)$. When ATP activates ionotropic P2X (found mainly in vascular smooth muscle cells), vasoconstriction occurs, while the activation of metabotropic $\mathrm{P} 2 \mathrm{Y}$ receptors (mainly found in endothelial cells) produces vasodilatation (28). Studies have shown that ADP is potent in platelet recruitment via interaction with P2Y12 receptors (14). The end product of the degradation of nucleotides, adenosine, induces relaxation of vascular smooth muscle (26).

Our results have shown that nucleotidases are activated in rat blood serum after one session of aerobic swimming exercise, suggesting that these enzymes may promote an increase in adenosine levels, which might be one of the mechanisms responsible for exercise-mediated vasodilatation.

\section{ACKNOWLEDGMENTS}

This work was supported by Conselho Nacional de Desenvolvimento Científico e Tecnológico (CNPq) and Coordenação de Aperfeiçoamento de Pessoal de Nível Superior (CAPES). M.R.S is recipient of fellowship PAPDRJ - CAPES/FAPERJ and C.D.B is recipient of the Research Productivity Fellowship from CNPq. The authors would to like to thank Dr. Floriano Paes Silva Jr. for his critical reading of the manuscript.

\section{REFERENCES}

1. Bradford, MM. (1976). A rapid and sensitive method for the quantification of microgram quantities of protein utilizing the principle of protein-dye binding. Anal Biochem, 72:218-254.

2. Böhmer, AE, Pochmann, D, and Sarkis, JJ. (2006). In vitro effect of homocysteine on nucleotide hydrolysis by blood serum from adult rats. Chem Biol Interact, 160:159-164

3. Burnstock, G. (2004). Cotransmission. Curr Op Pharmacol, 4:47-52.

4. Burnstock, G. (2006). Purinergic signalling--an overview. Novartis Found Symp, 276:26-48.

5. Burnstock, G. (2007). Purine and pyrimidine receptors. Cell Mol Life Sci, 64:1471-1483.

6. Chan, KM, Delfert, D, and Junger, KD. (1986). A direct colorimetric assay for $\mathrm{Ca}^{2+}$-stimulated ATPase activity. Anal Biochem, 157:375-380.

7. Chen, W, and Guidotti, G. (2001). Soluble apyrases release adp during ATP hydrolysis. Biochem Biophys Res Commun, 282:90-95.

8. Clifford, PS, and Hellsten, Y. (2004). Vasodilatory mechanisms in contracting skeletal muscle. J Appl Physiol, 97:393-403. 
9. Coade, SB, and Pearson, JD. (1989). Metabolism of adenine nucleotides in human blood. Circ Res, 65:531-537.

10. Delgado, JL, Landeras, J, Carbonell, LF, Parilla, JJ, Abad, L, Quesada, T, Fiol, G, and Hernández, I. (1999). Effect of Nacetylcysteine on vascular endothelium function in aorta from oophorectomized rats. Gen Pharmacol, 32:23-27.

11. Dunwiddie, TV, and Masino, SA. (2001). The role and regulation of adenosine in the central nervous system. Annu Rev Neurosci, 24:31-55.

12. Frassetto, SS, Dias, RD, and Sarkis, JJ. (1993). Characterization of an ATP diphosphohydrolase activity (APYRASE, EC 3.6.1.5) in rat blood platelets. Mol Cell Biochem, 129:47-55.

13. Fredholm, BB, Ijzerman, AP, Jacobson, KA, Klotz, KN, and Linden, J. (2001). International Union of Pharmacology. XXV. Nomenclature and classification of adenosine receptors. Pharmacol Rev, 53:527-52.

14. Gachet, C. (2000). Platelet activation by ADP: the role of ADP antagonists. Ann Med, 32:15-20.

15. Gobatto, CA, de Mello, MA, Sibuya, CY, de Azevedo, JR, dos Santos, LA, and Kokubun, E. (2001). Maximal lactate steady state in rats submitted to swimming exercise. Comp Biochem Physiol A Mol Integr Physiol, 130:21-27.

16. Harri, M, Kuusela, P. (1986). Is swimming exercise or cold exposure for rats? Acta Physiol Scand, 126:189-197.

17. Heptinstall, S, Johnson, A, Glenn, JR, and White, AE. (2005). Adenine nucleotide metabolism in human blood-important roles for leukocytes and erythrocytes. J Thromb Haemost, 3:23312339.

18. Mahaut-Smith, MP, Jones, S, and Evans, RJ. (2011). The P2X1 receptor and platelet function. Purinergic Signal, 7:341-356.

19. Marcus, AJ, Broekman, MJ, Drosopoulos, JH, Islam, N, Pinsky, DJ, Sesti, C, and Levi, R. (2003). Heterologous cell-cell interactions: thromboregulation, cerebroprotection and cardioprotection by CD39 (NTPDase-1). J Thromb Haemost, 1:2497-2509.

20. Mortensen, SP, Thaning, P, Nyberg, M, Saltin, B, Hellsten, Y. (2011). Local release of ATP into the arterial inflow and venous drainage of human skeletal muscle: insight from ATP determination with the intravascular microdialysis technique. $J$ Physiol, 589:1847-1857.

21. Oses, JP, Cardoso, CM, Germano, RA, Kirst, IB, Rucker, B, Furstenau, C.R. et al. (2004). NTPDase: An additional system of nucleotide hydrolysis in rat blood serum. Life Sci., 74:32753284.

22. Pieber, M, Valenzuela, MA, Kettlun, AM, Mancilla, M, Aranda, E, and Collados, L. Traverso-Cori, A. (1991). ATPase-ADPase activities of rat placental tissue. Comp Biochem Physiol B, 100:281-285.

23. Rådegran, G, Hellsten, Y. (2000). Adenosine and nitric oxide in exercise-induced human skeletal muscle vasodilatation. Acta Physiol Scand, 168:575-591.
24. Ralevic, V. (2000). P2 receptors in the central and peripheral nervous systems modulating sympathetic vasomotor tone. $J$ Auton Nerv Syst, 81:205-211.

25. Ralevic, V, and Burnstock, G. (1998). Receptors for purines and pyrimidines. Pharmacol Rev, 50:413-492.

26. Ralevic, V, and Burnstock, G. (2003). Involvement of purinergic signaling in cardiovascular diseases. Drug News Perspect, 16:133-140.

27. Roque, FR, Soci, UP, De Angelis, K, Coelho, MA, Furstenau, CR, Vassallo, DV, Irigoyen, MC, Oliveira, EM. (2011). Moderate exercise training promotes adaptations in coronary blood flow and adenosine production in normotensive rats. Clinics (Sao Paulo), 6:2105-2111.

28. Rosenmeier, JB, Yegutkin, GG, and González-Alonso, J. (2008). Activation of ATP/UTP-selective receptors increases blood flow and blunts sympathetic vasoconstriction in human skeletal muscle. J Physiol, 586:4993-5002.

29. Smith, TM, and Kirley, TL. (2006). The calcium activated nucleotidases: A diverse family of soluble and membrane associated nucleotide hydrolyzing enzymes. Purinergic Signal, 2:327-333.

30. Sakura, H, Nagashima, S, Nagashima, A, and Maeda, M (1998). Characterization of fetal serum 5'-nucleotide phosphodiesterase: a novel function as a platelet aggregation inhibitor in fetal circulation. Thromb Res, 91:83-89.

31. Soslau, G, and Youngprapakorn, DA. (1997). Possible dual physiological role of extracellular ATP in the modulation of platelet aggregation. Biochim Biophys Acta, 1355:131-140.

32. Todorov, LD, Mihaylova-Todorova, S, Westfall, TD, Sneddon, P, Kennedy, C, Bjur, RA, and Westfall, DP. (1997). Neuronal release of soluble nucleotidases and their role in neurotransmitter inactivation. Nature, 387:76-79.

33. Voltarelli, FA, Gobatto, CA, and de Mello, MA. (2002) Determination of anaerobic threshold in rats using the lactate minimum test. Braz J Med Biol Res, 35:1389-1394.

34. Yegutkin, GG. (1997). Kinetic analysis of enzimatic hydrolysis of ATP in human and rat blood serum. Biochemistry Mosc, 62:619-622.

35. Yegutkin, GG, Samburski, SS, and Jalkanen, S. (2003). Soluble purine-converting enzymes circulate in human blood and regulate extracellular ATP level via counteracting pyrophosphatase and phosphotransfer reactions. FASEB J, 17:1328-1330

36. Yegutkin, GG, Samburski, SS, Mortensen, SP, Jalkanen, S, and González-Alonso, J. (2007). Intravascular ADP and soluble nucleotidases contribute to acute prothrombotic state during vigorous exercise in humans. $J$ Physiol, 579:553-564.

37. Yegutkin, GG. (2008). Nucleotide- and nucleoside-converting ectoenzymes: Important modulators of purinergic signalling cascade. Biochim Biophys Acta, 1783:673-694.

38. Zimmermann, H. (2001). Ectonucleotidases: some recent developments and a note on nomenclature. Drug Develop Res, 52:44-56. 